\title{
Gender equality in the Arctic and North; socio-legal and geopolitical challenges
}

\author{
Åsa Gunnarsson ${ }^{1}$ \\ Umeå Forum for Studies on Law and Society, Umeå University, Sweden \\ Eva-Maria Svensson ${ }^{2}$ \\ Department of Law, University of Gothenburg, Sweden
}

Gender inequality and infringements of women's human rights are problems in all Arctic states and the geopolitics of the Arctic is gendered (CEDAW country reports; Nymand Larsen and Findahl 2015). Much of the economic gains have not been re-invested in the Artic region, suffering under what has been conceptualized as the 'Paradox of Plenty' (Lahey, Svensson and Gunnarsson 2014). The concept, also called the resource curse, aims to capture the exploitation of economies that rely heavily on natural resources. It was already recognized in the 1950s that low- and middle income countries, living on natural resources such as fossil fuels and minerals had comparatively low economic growth, low levels of democratic development, and large public deficits. However, the syndrome is not isolated to developing economies. Irrespective of the level of wealth and welfare structure in a state or a region, the abundance of natural resources seems to fuel the economy with quick cash that drains long-term social investments and under-develops sectors that are irrelevant for the natural resource industry. Consequently it drains public budgets and creates increased inequalities, and is particularly devastating for the progress of gender equality between men and women (Lahey 2015).

The Arctic as a geopolitical space is formed in a nexus of conflicting interests, supposedly balanced by intergovernmental bodies established by the affected states (Dittmer et al. 2011). Koivurova has described the area as "an extension of existing political, economic, and environmental systems" (Koivurova 2014). It is a subject for international cooperation between eight states, and defined in intergovernmental bodies that also have included NGOs, IPOs and observers. The public governance is consolidated by policies, agreements, soft law and legal regulations.

\footnotetext{
${ }^{1}$ Address: Åsa Gunnarsson, Umeå Forum for Studies on Law and Society, Umeå University, S-901 87 Umeå, Sweden. E-mail: asa.gunnarsson@umu.se

${ }^{2}$ Address: Eva-Maria Svensson, Department of Law, School of Business, Economics and Law, University of Gothenburg, Box 650, SE-405 30 Gothenburg, Sweden. E-mail: eva-maria.svensson@law.gu.se
} 
The Arctic has become increasingly interesting for the international community as an area of economic importance due to natural resources and increased access to sea and land (Ebinger and Zambetakis 2009) resulting in climate, economic, social and legal implications for people living in the region. These interests expose the Arctic to a huge load from economic activities, activities that at the same time produce wealth and revenues for society. Economic interests of the extraction industry, as well as of the nation-states, risk colliding with the interests of the people living in the region. Human development can even be contradictory to economic development (Einarsson et al. 2004). Human development has clearly not been in the forefront in the Arctic region, but rather adaptive to other interests (Svensson 2017). The Arctic space has been characterized as a representation of a masculine fantasy of adventure and exploitation (Dittmer et al. 2011). Men and women are not affected equally by climate change and globalization as well as its impact on economic activities, political systems, education and health care provisions (Naskali et al. 2015). Such aspects, together with rurality, also create a specific context and vulnerability for sexual exploitation and violence against women (LahiriDutt 2006).

The political actors of the Arctic, among which the Arctic Council is a key actor (Heininen 2012; Nord 2016b), form the politics but are also producers of knowledge-based discourses and representations of the Arctic. Central in this project is that multi-level governing bodies exercise power and are as knowledge-producers forming the Arctic, gender and gendered structures, for example in the scientific reports of the Arctic Council (SinevaaraNiskanen 2015; Kankaanpää 2012; Heininen 2012). Left aside in the AHDR I (Einarsson et al. 2004) were for example the intersections of different power structures such as gender and indigeneity or gender and rurality.

The governance of the Arctic has for the past three decades been of central concern for research (e.g. Koivurova 2012). The interest in outlining the needs and principles around which a system of governance for the Arctic should be constructed has expanded (Nord 2016a). The studies show that even if the concerns regarding national security and natural resource exploitation have been prioritized, environmental protection and sustainable development (the 'twin pillars' of the Arctic Council) have gained increased interest over time (Nord 2016b), a development asked for by some scholars (Keskitalo 2004). However, gender equality and women's human rights law and policies are blind spots in the geopolitics of the Arctic (Lahey, Svensson and Gunnarsson 2014). The political actors have ignored these issues (Lahey, Svensson and Gunnarsson 2014; Svensson in this issue). This includes Sweden, when holding the Chairmanship, despite explicitly expressed ambitions (Nord 2016a). As Arctic states, the Nordic countries, 
not the least Sweden with its feminist foreign policy with high ambitions when it comes to gender equality, could be a driving force in putting human development at the forefront of Arctic geopolitics.

This first issue of the Nordic Journal on Law and Society (NJOLAS) is dedicated to the theme of gender in the arctic, which is our contribution to the initiative of Umeå University (UmU) to announce the Arctic as a priority for 2017. The initiative of this special issue is the result of research carried out by members of a transnational, socio-legal and interdisciplinary network on gender studies on women's every-day life in Arctic and Northern Regions. The name TUARQ, represents the first letters of the university cities to which the network researchers are now affiliated; Tromsö, Umeå, Arkhangelsk, Rovaniemi, and Quebec. The network was initially built around a three-part collaboration between UiT the Arctic University of Norway (UiT), UmU and Northern (Arctic) Federal University named after M. Lomonosov (NArFU). The network has received strategic funding from UiT and UmU on several occasions for its relevance to internationalisation of research and Arctic collaboration. Funding has also been granted by the Nordic Arctic Co-operation Program monitored by NordRegio.

In May 2011 the first workshop on Nordic regional aspects on gender, taxes and social security was arranged by UiT in Tromsö. It was followed by a second workshop on Gender Law in September the same year, also held in Tromsö, in connection with a conference on legal systems in the Barents Euro-Arctic region. The third network meeting was arranged in the form of a conference in Archangelsk, hosted by NArFU at end of June 2012, about cross-disciplinary comparative studies of public mechanisms for gender equality. Gender and Arctic Directions was a workshop which took place at UmU between 6 - 8 May, 2013. The fifth meeting was held as a conference on the topic Arctic/Northern Women: Situating Law and Justice in Development and Equality. It was arranged by Feminist Legal Studies Queen's at Queen's University, Canada, and took place at the end of February in 2014. UmU hosted the last meeting on Gender and everyday perspectives in the Arctic, 7-8 May 2015, and will also host the upcoming meeting in October 2017 arranged in collaboration with the research project 'Advancing Elderly People's Agency and Inclusion in the Changing Arctic and Nordic Welfare' monitored by Päivi Niskali at the University of Lapland. The articles in this special issue are outcomes of all these events arranged by TUARQ. Manuscripts have been presented and reviewed as a part of the academic discussions.

One of the initial ambitions of TUARQ has been to identify legal, socioeconomic and cultural barriers to gender equality faced by people living in the geopolitical areas of the High North or the Arctic region. How public 
governance through regulation, organization, policies and actions acknowledges gender inequality and promote gender equality related to welfare and sustainability are central research topics concerning these barriers. The network furthermore aims at providing analysis of the interaction between gender equality law and policies, welfare politics and sustainable development, and the relation between gender equality and indigenous rights in the region.

This socio-legal research takes as its starting-point a firm conviction that, in order to promote social sustainable community development in the Arctic, a rethinking of the prioritization and relation between economic interests and social and environmental interests is needed. The legal obligations of multi-level governance of the Arctic must be considered in a broader context, addressing presumptions about the geopolitics of the Arctic as a space in which gender equality, along with the human development and social sustainable development, seems to be considered as a consequence of other concerns rather than a starting-point for governing concerns (Lahey, Svensson and Gunnarsson 2014; Svensson 2017).

Researching gender equality in the Arctic region produces unique knowledge with the potential to have an impact among stakeholders with an interest in how this geopolitical area is governed and developed. The aim is to contribute with some insights on the importance of integrating gender equality policies in the future challenges for welfare and sustainability programs for the region. A quite immediate interest was shown by the Arctic Council when inviting representatives of the network to the Arctic Council's open seminars in Kiruna, May 14, 2013, in a panel discussion about challenges in the Arctic from a gender perspective. An outcome of this discussion was a new invitation to a conference on Gender Equality in the Arctic: Current Realities and Future at Akureyri, Iceland, October 30-31, 2014. Eva-Maria Svensson was specially invited from the network as a plenary speaker regarding gender dimensions of political representation and participation. The speech is published in the conference report (Svensson 2015).

Other conferences where the network researchers have presented results are:

-the Law and Society Association annual conference in New Orleans, 2-5 June 2016, in which network members presented texts of which some are part of this special issue,

-the Polar law symposium on The role of law in Polar governance at Akureyri and Reykjavik, Iceland 5-9 October 2016, ${ }^{3}$

\footnotetext{
${ }^{3}$ (Burman, Svensson and Wennberg.) forthcoming.
} 
-the Nordic Law and Gender Conference in Turku, 11-12 May 2017, and

-ICASS IX People and Place, at Umeå University, 8-12 June 2017, in which a session was organised by TUARQ on Toward a gender equal human development in the Arctic.

The first contribution in this issue is a good example on what new knowledge a gender perspective on the governance of the Arctic region can bring. The initial article by Eva-Maria Svensson explores the lack of gender equality commitments in the regional governance structures of the Arctic Region. She considers how the obligations to take measures to eliminate gender inequality and to promote gender equality following the ratification of the CEDAW treaty, which apply to all dimensions of government action, including any actions states take in international cooperation with other states, have affected governance of the Arctic region. Svensson provides a comprehensive survey of the regional governance organizations, but focuses on The Arctic Council, established by the Ottawa Declaration in 1996 by the eight circumpolar states. The aim of the Arctic Council, as a high level intergovernmental forum for the Arctic region in all, was to "provide a means for promoting cooperation, coordination and interaction among the Arctic States, with the involvement of the Arctic Indigenous communities and other Arctic inhabitants on common Arctic issues, in particular issues of sustainable development and environmental protection in the Arctic." 4 However, as Svensson points at, the Arctic Council has taken very few steps to ensure that women "represent their Governments at" and "participate in the work" of the Council "on equal terms with men" as required by CEDAW (art. 8). As a consequence, gender-based analysis used to identify relevant issues and knowledge specific to the region in order to promote sustainable development are almost non-existent and, what is more, human sustainable development (and also environmental protection) is constructed as reactive in relation to economic development in the geopolitics of the Arctic.

Hanne Petersen uses a gendered and also personal perspective in an attempt to bring together links and similarities in the societal challenges the Arctic region is so rapidly facing. The experienced-based research she presents about this development is based in Greenland and China. To compare links and similarities in the conflicting interests and influential elements that change social infrastructures, gender relations, norms and geo-political landscapes in such divergent parts of the world, Petersen uses the essay as a genre. Petersen reflects on whether (gender) justice and morality, in a globalized and commercialized world, will be considered as important in the Arctic as stability, harmony and security.

\footnotetext{
${ }^{4}$ Arctic Council, Declaration on the Establishment of the Arctic Council. September 19, 1996: art. 1(a), https://oaarchive.arctic-council.org/bitstream/handle/11374/85/EDOCS-1752-v2ACMMCA0O_Ottawa_1996_Founding_Declaration.PDF? sequence $=5$ \&isAllowed=y
} 
How mobility practices are changed, and how these changes have an impact on gender contracts in the High North of Norway is in focus for Siri Gerrrard's article. Based on data collection from Gerrard's lifelong engagement with gender issues in fishery villages, and combining perspectives from gender research, anthropology and geography, the article contributes to a greater understanding of the interrelations between structural, material and cultural changes in the context of small-scale coastal fishing environments. She addresses the question of whether changes in mobility practices related to restructuring of the fisheries by means of a quota-system, Norway's agreement with the European Union (EEA), and other changes in the Norwegian context, have had impact on gender contracts and in what way. Gerrard concludes that, overall, mobility patterns that had previously been driven by male choices now appear to be decided by men and women together. The previously important link between settlement and work is weakened. At the same time fisheries have become even more male dominated, and gender relations overall have become more varied and multicultural. What is also observed are the increased demands for flexibility between the spouses, as they face greater variation in organization of daily life compared with earlier years. Despite these crosscutting changes, however, she concludes that men's incomes and wealth continue to form the core of household support in these communities, with no variation based on mobility or migration patterns.

The following two articles also deal with gender equality issues in the High North of Norway, concentrating on multicultural cross border marriages between Russian women and Norwegian men. Natalia Kukarenko addresses the segregating consequences of those normalization processes that the Norwegian gender system impose on Russian migrant women. As the gender systems of Soviet and Post-Soviet radically differ from the Norwegian system in terms of gender equality policies, the social identities of Russian women marrying Norwegian men face the risk of being lower ranked in a societal hierarchy. This process defines Russian women as the "other" women, that are characterized as less gender equal, less independent, and also morally questionable, which can become a trap for this minority group.

The focus in Hege Brækhus' article is on the legal situation for those many migrating women crossing the borders from North-West of Russia after the fall of the Iron Curtain through marriage in the northernmost county in Norway, Finnmark. The study explores how legal commitments to gender equality have shaped the status of women in situations of multicultural marriages or migrating families. Brækhus analyses the question of when and how Norwegian law applies to Russian women who emigrated to Norway and married Norwegian men, and how their immigration status and the lack of bilateral agreements between Norway and Russia as to 
matrimonial and parental issues affects their rights on separation, divorce, or bereavement. Brækhus identifies gender-specific legal barriers that arise from the structural impact of their situation, such as a prohibition on work permits for three years after arrival causing economic dependency in marriage, and the lack of agreements concerning children of transnational marriages. The conclusion is that intersecting and interlocking hierarchies perpetuate non-immigrant Norwegian privilege.

An interesting parallel to the studies on the vulnerable social and legal situation for Russian women in the High North of Norway is presented by Tatiana Zykina and Ekaterina Sazanova in the article on the labour rights of Russian women. While the principle of gender equality is widely incorporated in Russian law, Zykina and Sazanova reveal that, in reality, Russian women suffer many forms of discrimination and are unable to realize their right to equal opportunities in the labour force. Current research findings show that the situation for women when it comes to employment and income levels, specific to the Arkhangelsk region, is deteriorated. There is a general tendency, the authors state, to consider women as a secondary labour force or as a reserve. According to patriarchal traditions, men are perceived as the main breadwinners and women are something additional to their husbands and it is also considered that the size of a woman's salary should reflect this prejudice. The prejudice justifies discrimination in working life, both in private and in public sector even though discriminatory practices are a greater problem in the private sector. Zykina and Sazanova concludes with several detailed recommendations on points of change needed at the firm and individual employee levels as well as in the overall regulation of paid work.

Gender equality policies and law are integrated parts of welfare state programs, so when the welfare state confronts new societal challenges, it is important to consider the effects that will bring on gender equality concerns. Lena Wennberg shows in her article how transformations of the welfare state as well as social and demographic changes affect the wellbeing of aging people and their living conditions in the most northern county of Swedish, Norrbotten, that is a part of the Barents Euro-Arctic region. The welfare state is transformed into an anti-regulative welfare society that increasingly privatizes formerly public services. At the same time, in Sweden, new statutory pronouncements of rights to live in dignity and wellbeing are introduced as a means of steering of the management of care services. They are meant to clarify the fundamental normative and ethical values for elder care and guarantee older people equal care services throughout the whole country to live in dignity. However, the values do not form a legal basis to assess whether a person is entitled to the welfare services or care needed for a reasonable standard of living. There are 
differences in how the municipalities choose to organize, prioritize and perform welfare services, in public or private regime, depending on the financial situation and political will in each municipality. Wennberg reflects upon whether human rights and discrimination law, presupposing and strengthening individual autonomy, could be a tool for strengthening the wellbeing and gender equality of elderly people in northern and Arctic contexts. The conclusion, stated by Wennberg, is that national welfare systems need to be subjected to further socio-legal and interdisciplinary analyses in the context of the various local and specific conditions in which people age/grow old.

The relation between national gender equality policies and indigenous rights is the topic of Monica Burman's article. She approaches a set of Nordic equality expectations in the form of the view that men's violence against women is one of the highest priority gender equality issues in Sweden. At the same time, men's violence against Sami women is a blind spot, according to Burman. She uses the example of Sami women's lack of equal legal status under the Reindeer Herding Act, and postulates that the combination of unreconstructed colonial policies and failure to recognize the realities of Sami women's lives under these policies leaves little room for addressing Sami violence against women in any meaningful way. In order to fill the void she maps out applicable human rights treaties and laws, government policies, research studies, Sami organizations, and domestic laws, and identifies what needs to change in order to put this silent and invisible issue on the social, policy, and legal agenda. Grounding her examination in the provisions of both international gender equality and indigenous peoples rights documents, Burman points out that Sweden has repeatedly been urged by the CEDAW Committee to address this problem, but has not yet done so in the context of the wider recognition and protection of indigenous women's rights. Nor has the Sami Parliament. In addition, she posits the responsibility that must be taken by the researcher. Research relating to indigenous peoples performed by non-indigenous researchers can be a form of colonialism in itself. Understanding and acknowledging the colonial process and the Sami experiences that are marked by colonialism are essential in trying to avoid doing more harm than good. And, in research on violence against Sami women, Sami women themselves and relevant Sami organizations must be the priority stakeholders and involved as experts in the project in ways that give them real possibilities to impact on the research.

Together, the articles form a socio-legal contribution to fill an identified knowledge gap about gender equality in the Arctic and in the geopolitics of Arctic. 


\section{References}

Burman, Monica, Svensson, Eva-Maria and Wennberg, Lena. Forthcoming. The role of international human rights law in the governance of the Arctic regarding women's rights. Submitted to The Yearbook of Polar Law IX. Leiden. Brill / Nijhoff.

Dittmer, Jason, Moisio, Sami, Ingram, Alan and Dodds, Klaus. 2011. Have you heard the one about the disappearing ice? Recasting Arctic geopolitics. Political Geography 30 (4): 202-14.

Ebinger, Charles and Zambetakis, Evie. 2009. The Geopolitics of Arctic Melt. International Affairs 85 (6): 1215-1232.

Einarsson, Niels, Larsen, Joan Nymand, Nilsson, Annika and Young, Oran R (eds.). 2004. Arctic Human Development Report (AHDR I). Akureyri: Stefansson Arctic Institute.

Heininen, Lassi. 2012. Arctic Strategies and Policies: Inventory and Comparative Study. Rovaniemi: The Northern Research Forum \& The University of Lapland.

Kankaanpää, Paula. 2012. The Arctic Council - from Knowledge Production to Influencing Arctic Policy Making. In Timo Koivurova, Gudmundur Alfredsson and Waliul Hasana (eds.). The Yearbook of Polar Law IV. Dordrecht: Martinus Nijhoff Publishers, 59-76.

Keskitalo, Eva Carina Helena. 2004. Negotiating the Arctic: The Construction of an International Region. New York and London: Routledge.

Koivurova, Timo. 2012. The Future of Arctic Governance. In Tore Henriksen (ed.). Juss i Nord: hav, fisk og urfolk: en hyllest till Det juridiska fakultet ved Universitetet I Tromsøs 25-årsjubileum. Oslo: Gyldendal Juridisk.

Koivurova, Timo. 2014. The Arctic Council: A Testing Ground for New International Environmental Governance. Brown Journal of World Affairs. XIX (1): 131-144.

Lahey, Kathleen, Svensson, Eva-Maria and Gunnarsson, Åsa. 2014. Gender Challenges \& Human Capital in the Arctic'. In Lasse Heininen and Heather Exner Pirot (eds.). Arctic Yearbook 2014. Akureyri: Iceland, Northern Research Forum, 183-201.

Lahey, Kathleen. 2015. The Alberta Disadvantage: Gender, Taxation, and Income Inequality. Edmonton: Parkland Institute.

Lahiri-Dutt, Kuntala and Macintyre, Martha. 2006. Women Miners in Developing Countries. Pit Women and Others. Aldershot: Ashgate.

Naskali, Päivi., Seppänen, Marjaana and Begum, Shahnaj (eds.). 2015. Ageing, Wellbeing and Climate Change in the Arctic: an interdisciplinary analysis. London \& New York: Routledge.

Nord, Douglas, C. 2016a. The Changing Arctic: Creating a Framework for Consensus Building and Governance within the Arctic Council. Hampshire and New York: Palgrave Macmillan. 
Nord, Douglas C. 2016b. The Arctic Council: Governance within the Far North. London and New York: Routledge.

Nymand Larsen, Joan and Findahl, Gail (eds.). 2015. Arctic Human

Development Report: Regional Processes and Global Linkages (AHDR II). Copenhagen: Nordisk Ministerråd.

Sinevaara-Niskanen, Heidi. 2015. Vocabularies for human development: Arctic politics and the power of knowledge. Polar Record 51 (2): 191-200.

Svensson, Eva-Maria. 2015. Gender Equality in Public Governance of the Arctic. In Iceland. Ministry for Foreign Affairs in cooperation with Icelandic Arctic Cooperation Network and the Centre For Gender Equality. Gender Equality in the Arctic: Current Realities and Future Challenges. Reykavik: Ministry for Foreign Affairs, 26-27.

Svensson, Eva-Maria. 2017. Feminist and Environmentalist Public Governance in the Arctic. In Lill-Ann Körber, Scott MacKenzie and Anna Westerståhl Stenport (eds.). Arctic Environmental Modernities From the Age of Polar Exploration to the Era of the Anthropocene. Basingstoke: Palgrave Macmillan, 215-230. 